\title{
First record of fossil ant species Eocenomyrma rugosostriata (Mayr) (Hymenoptera: Formicidae) from the Rovno amber
}

\author{
Первая находка муравья Еосепоmyrma rugosostriata (Mayr) \\ (Hymenoptera: Formicidae) в ровенском янтаре
}

\author{
A.G. Radchenko, E.E. Perkovsky \\ А.Г. Радченко, Е.Э. Перковский
}

\begin{abstract}
Schmalhausen Institute of Zoology, NAS of Ukraine, B. Khmelnitskogo str., 15, Kiev, 01030, Ukraine. E-mail: rad@izan.kiev.ua; perkovsk@gmail.com
\end{abstract}

KEY WORDS: ants, amber, Late Eocene, Europe, Subparathetys, palaeontology.

КЛЮЧЕВЫЕ СЛОВА: муравьи, янтарь, поздний эоцен, Европа, Субпаратетис, палеонтология.

ABSTRACT. Three species from the extinct ant genus Eocenomyrma (E. orthospina Dlussky et Radchenko, 2006, E. ukrainica Radchenko et Dlussky, 2016 and E. breviscapa Radchenko et Dlussky, 2016) were previously recorded or described from the Rovno amber (Klesov, Sarny Distr., Rovno Reg., Ukraine). Eocenomyrma rugosostriata (Mayr) was beforehand known from the Baltic and Bitterfeld ambers, and it is recorded here for the first time from the Rovno amber (Voronki, Vladimirets Distr.). It is $79^{\text {th }}$ ant species and $117^{\text {th }}$ hymenopteran species that are known from the Rovno amber; just 59 hymenopteran species (50\%) are common in the Rovno and Baltic ambers. Eocenomyr$m a$ ants are represented by three species on the northern coast of Subparathetys (Baltic amber) and by five species (two species common with Baltic amber) on the southern coast of Subparathetys (Rovno, Bitterfeld and Scandinavian ambers).

РЕЗЮМЕ. Три вида вымершего рода муравьёв Eocenomyrma (E. orthospina Dlussky et Radchenko, 2006, E. ukrainica Radchenko et Dlussky, 2016 and E. breviscapa Radchenko et Dlussky, 2016) были ранее указаны или описаны из ровенского янтаря (Клёсов, Сарненский р-н., Ровенская обл., Украина). Eосепоmyrma rugosostriata (Mayr) был ранее известен из балтийского и саксонского янтарей, в настоящей статье он приводится впервые для ровенского янтаря (Воронки, Владимирецкий р-н). Это 79-й вид муравьев и 117-й вид всех перепончатокрылых насекомых, известных из ровенского янтаря; лишь 59 видов перепончатокрылых (50\%) являются общими для ровенского и балтийского янтарей. Род Еосепоmyrma представлен тремя видами на северном побережье Субпаратетиса (балтийский янтарь), и пя- тью видами (два из которых общие с балтийским янтарем) на его южном побережье (ровенский, саксонский и скандинавский янтари).

The extinct ant genus Eocenomyrma was established by Dlussky and Radchenko [2006] and included at that time four species, found in the Late Eocene Baltic, Bitterfeld and Scandinavian ambers (Priabonian stage, 33.937.2 Mya): E. orthospina Dlussky et Radchenko, 2006 (type species of the genus), E. elegantula Dlussky et Radchenko, 2006, E. electrina Dlussky et Radchenko, 2006, and E. rugosostriata (Mayr, 1868), though members of this genus are rare in all representative Late Eocene European amber collections [Dlussky, Rasnitsyn, 2009]. Recently two more new species of this genus, $E$. ukrainica and E. breviscapa, were described from the Rovno amber [Radchenko, Dlussky, 2016].

Mayr [1868] described Macromischa rugosostriata based on two workers from the Baltic amber. Later on Wheeler [1915] found nine more workers and one queen of this species from this amber and transferred it to the established by him new genus Nothomyrmica Wheeler. Dlussky and Radchenko [2006] transferred Nothomyrmica rugosostriata to the genus Eocenomyrma, designated the neotype of this species from the Bitterfeld amber and redescribed it based on three workers from the Bitterfeld and Baltic ambers. At last, Radchenko and Dlussky [2016] provided data on one more worker specimen of E. rugosostriata from the Baltic amber.

Thus, till now E. rugosostriata seems to be the commonest member of this genus - in total, 16 specimens of this species are found in the Baltic, Bitterfeld and Rovno ambers, while only seven specimens attributed to other five Eocenomyrma species are found till now. One species (E. orthospina) is known from both

How to cite this article: Radchenko A.G., Perkovsky E.E. 2018. First record of fossil ant species Eocenomyrma rugosostriata (Mayr) (Hymenoptera: Formicidae) from the Rovno amber// Russian Entomol. J. Vol.27. No.3. P.285-288. doi: 10.15298/rusentj.27.3.08 



Figs 1-2. Photo of Eocenomyrma rugosostriata, worker, collection number SIZK L-30, AntWeb CASENT number 0917571: 1 — lateral view from the left; 2 - dorso-lateral view from the right (Photo by E. Martynova).

Рис. 1-2. Фото Eocenomyrma rugosostriata, рабочий, коллекционный номер SIZK L-30, AntWeb CASENT number 0917571: 1 вид сбоку-слева; 2 - дорсо-латеральный вид справа (фотография Е. Мартыновой). 
Rovno and Baltic ambers, and each of other species are found in the single of four Late Eocene European ambers [Dlussky, Radchenko, 2006; Dlussky, Rasnitsyn, 2009; Radchenko, Dlussky, 2016]. At the same time, four of six Eocenomyrma species are known from the Rovno amber that makes this fauna the richest among all other ambers. Only three species are known from the northern coast of Subparathetys (Baltic amber) and solely E. elegantula is known only from Baltic amber. However, five Eocenomyrma species are found in at least 6.5 times smaller in number of specimens collections from the southern coast of Subparathetys (Rovno, Bitterfeld and Scandinavian ambers), including three species unknown from the Baltic amber. It seems that Eocenomyrma ants were at least less diverse on the northern coast of Subparathetys.

116 hymenopteran species [Perkovsky, 2018], including 78 ant species, were recorded from the Rovno amber till now, and 28 ant species belong to the subfamily Myrmicinae [Perkovsky, 2016; Radchenko, Dlussky, 2016,2018 , a,b]. E. rugosostriata is $79^{\text {th }}$ ant species and $29^{\text {th }}$ myrmicine one known from this amber. Just 59 hymenopteran species $(50 \%$ of the total number in ambers) are common now in both Rovno and Baltic ambers, and 37 species are common in both Rovno and Bitterfeld ambers (33\%).

For the comparison, 77 species and 27 myrmicine genera (including not yet described ones) are known in total from all Late Eocene European ambers [Radchenko, Dlussky, 2018a]. 16 species and 3 genera of them are known only from the Rovno amber, what well corresponds with big myrmicine share in the Rovno amber, at least not in the smallest weight fractions of ambers [Perkovsky, 2009].

Here we recorded for the first time E. rugosostriata from the Rovno amber (Figs 1-2). A single worker was found recently in the piece of amber weighting $23 \mathrm{~g}$ (after primarily treatment). All previously known EOcenomyrma species from the Rovno amber were found in Klesov, but E. rugosostriata was collected in another locality: Vladimirets Distr., $10 \mathrm{~km} \mathrm{~N}$ of vil. Voronki.

This specimen is stored in the collection of Schmalhausen Institute of Zoology of NAS of Ukraine, Kiev (SIZK, collection number L-30). There are following syninclusions in the same piece of amber: L-30a, Acari, Anystidae; L-31, Chironomidae female, Acari, Oribatei; L-32, Lepidoptera; L-33, Empididae; L-34, Chironomidae, Chironominae, male; L-35, Scirtidae; L-36, 3 Collembola (1 Symphypleona, 2 Entomobryomorpha), Diptera (Sciaroidea), Acari; L-37, Staphylinidae, Scydmaeninae), 2 Chironomidae, females, Phoridae, Sciaridae, spider web; L-38, Chironomidae, female; L39, Cicadinea, Coccinea, 2 Diptera (Cecydomyiidae and Sciaroidea), Collembola Symphypleona.

Below we give the measurements of this worker of E. rugosostriata (for abbreviations see Radchenko and Dlussky, 2016), and photographs of thøû specimen.

The photographs were taken with Leica Z16 APO microscope equipped with Leica DFC 450 camera and processed by LAS Core software.
Measurements (in $\mathrm{mm}$ ) of E. rugosostriata: total length 4.64, HL 1.05, HW 0.94, SL 0.62, FW 0.52, FLW 0.55 OL 0,21, ML 1.52, MH 0.62, PL 0.46, PH 0.31, PPL 0.35 , PPH 0.31, HTL 0.53, ESL 0.36, ESD 0.27.

Ratios: HL/HW 1.13, SL/HL 0.59, SL/HW 0.67, FW/HW 0.56, OL/HL 0.20, PL/PH 1.46, PL/HW 0.49, PPL/PPH 1.13, ESL/HW 0.39, ESD/ESL 0.75, ML/ MH 2.44.

\section{Discussion}

Eocenomyrma rugosostriata appears not only the commonest species of the genus, but the species with widest known distribution as well. Seems interesting, that the same concerns another nearly simultaneous hymenopteran finding from Voronki - Dryinus janzeni Olmi, 2000 (Dryinidae). Dryinus janzeni is the commonest Dryinus species of group 3 [Olmi, 1993] and it is the first pincer wasp from the Rovno amber [Perkovsky, Olmi, 2018] now recorded from both Baltic and Rovno amber. Group 3 of Dryinus is thermophilic, only one of nine Palaearctic species of group 3 distributed in the temperate regions [Olmi, 1999; Olmi, Xu, 2015] and all of Palaearctic species are only found in northern part of the group 3 distribution [Perkovsky, Olmi, 2018]. Three species of this group, D. janzeni, D. bruesi (Olmi, 1984) and D. balticus (Olmi, 1984) are known from understudied Rovno and Scandinavian ambers, which are originated from the warmer southern coast of the Subparathetys, and three species are known from the Baltic amber - the best studied amber Lagerstätte in the world. Only one Baltic amber species of the group 3 is unknown from other ambers. We supposed that such distribution of the Dryinus species of group 3 is connected with the thermophily of the group [Perkovsky, Olmi, 2018]. Eocenomyrma ants are represented by three species in Baltic amber (only one of them is unknown from other ambers) and by five species from the southern coast of the Subparathetys, and most probably it indicates thermophily of the genus.

ACKNOWLEDGEMENTS. We sincerely grateful to Radion N. Khomich (Rovno) for donating the amber sample for investigation, and to Anatoly P. Vlaskin (SIZK) for cutting and polishing the piece of amber, and to Ekaterina $\mathrm{V}$. Martynova (SIZK) for the making images of the worker of $E$. rugosostriata.

\section{References}

Dlussky G.M., Radchenko A. 2006. Fallomyrma gen. nov. , a new myrmicine ant genus (Hymenoptera: Formicidae) from the Late Eocene European amber// Annales Zoologici. Vol.56. No.1. P.153-157.

Dlussky G.M., Rasnitsyn A. P. 2009. Ants (Insecta: Vespida: Formicidae) in the Upper Eocene amber of Central and Eastern Europe // Paleontological Journal. Vol.43. No.9. P.1024-1042.

Mayr G. 1868. Die Ameisen des baltischen Bernsteins // Beiträge zur Naturkunde Preussens. Königlichen physikalisch-ökonomischen Gesellschaft zu Königsberg. Bd.1. S.1-102. 
Olmi M. 1993. A new generic classification for Thaumatodryininae, Dryininae and Gonatopodinae, with descriptions of new species (Hymenoptera Dryinidae) // Bollettino di Zoologia agraria e di Bachicoltura. Ser.II. Vol.25. P.57-89.

Olmi M. 1999. Hymenoptera Dryinidae — Embolemidae // Fauna d'Italia. T.37. Edizioni Calderini, Bologna. 425 pp.

Olmi M., Xu Z. 2015. Dryinidae of the Eastern Palaearctic region (Hymenoptera : Chrysidoidea)// Zootaxa. Vol.3996. P. 1-253. http://dx.doi.org/10.11646/zootaxa.3996.1.1

Perkovsky E. E. 2009. Differences in ant (Hymenoptera, Formicidae) species composition between weight fractions of Rovno Amber // Paleontological Journal. Vol.43. No.9. P.1087-1091.

Perkovsky E.E. 2016. Tropical and Holarctic ants in Late Eocene ambers// Vestnik Zoologii. Vol.50. No.2. P.111-122.

Perkovsky E.E. 2018. Only a half of species of Hymenoptera in Rovno amber is common with Baltic amber // Vestnik Zoologii. Vol.52. No.5 [in press].
Perkovsky E.E., Olmi M. 2018. Discovery of the first pincer wasp (Hymenoptera, Dryinidae) in Rovno// Zootaxa. Vol.4457. No.2. P.296-304. https://doi.org/10.11646/zootaxa.4457.2.5.

Radchenko A.G., Dlussky G.M. 2016. Further data on the extinct ant genus Eocenomyrma (Hymenoptera, Formicidae) // Vestnik Zoologii. Vol.50. No.5. P.395-406.

Radchenko A., Dlussky. G.M. 2018a. Ants of the genus Fallomyrma Dlussky et Radchenko (Hymenoptera, Formicidae, Myrmicinae) from Late Eocene European ambers // Paleontological Journal. Vol.52. No.2. P.155-163.

Radchenko A., Dlussky. G.M. 2018b. Two new fossil species of the ant genus Pristomyrmex Mayr (Hymenoptera, Formicidae) from the Rovno and Bitterfeld ambers // Annales Zoologici. Vol.68. No.2. P.251-258.

Wheeler W.M. 1915. The ants of the Baltic Amber // Schriften der Physikalisch-ökonomischen Gesellschaft zu Königsberg in Pr. Bd.55. H.2. S.1-142. 